\title{
TOURISM ACTIVITY IN THE THIRD AGE GROUP: ITS CHARACTERISTICS ON SELECTED EXAMPLES
}

\author{
PIOTR OLEŚNIEWICZ, ${ }^{1}$ JULITA MARKIEWICZ-PATKOWSKA, ${ }^{2}$ \\ KRZYSZTOF WIDAWSKI ${ }^{3}$ \\ ${ }^{1}$ University School of Physical Education in Wrocław, POLAND \\ e-mail: e-mail: piotr.olesniewicz@awf.wroc.pl \\ ${ }^{2}$ WSB University in Wrocław, POLAND \\ e-mail: julita.markiewicz-patkowska@wsb.wroclaw.pl \\ ${ }^{3}$ University of Wrocław, POLAND \\ e-mail: krzysztof.widawski@gmail.com
}

KEYWORDS $\mid$ senior tourism, tourist motivations, tourism development inhibitors, tourist offer

ABSTRACT

The article refers to the functioning and development perspectives of senior tourism based on the opinion of two active senior sections members of an association dedicated to sport promotion. A short presentation of the association activity is followed by an analysis of the survey responses. The research was performed among 68 seniors. The questions concerned four main topics: the respondents' personal status and physical condition, the preferred forms of recreational activity, the main purposes of travelling and tourist motivations, and, finally, the most important factors inhibiting the responders' tourist activity. The group was also asked to assess the tourist offer existing on the local market in Lower Silesia, and especially to emphasise factors that should be changed.

\section{Introduction}

The ageing of the societies in the developed countries is a fact. The process has been observed for years, with a specific culmination point, at least in Europe, in the year of 2004, when the number of seniors - people aged over 65 - exceeded the number of the youngest population (under 14 years of age) with the ratio of 75.4 million to 74 million. In the recent decade, every sixth inhabitant of our continent was over 65 years of age (Alén, Domínguez, Losada, 2012), and the situation is still 
dynamically changing. As Śniadek points (2006), in 2020, 25\% of the European Union inhabitants will belong to the $60+$ group. Every 6 seconds, the number of seniors in Europe increases by one.

\section{Identification and explanation of the issue}

\section{Senior definition}

In the context of an attempt to assess senior tourism functioning, the group that the phenomenon refers to should be determined first. In fact, some discrepancies can be observed here already. Hossain, Bailey, and Lubulwa (2003) use the term senior with regard to the age group of 55+, and the term non-senior for the group aged 15-55 years. Moreover, they divide the senior group into elder seniors (aged 65+) and younger seniors (between 55 and 64 years of age). In Alcaide's approach (2005), the senior age begins with 55 years of age. He considers this moment a significant turning point, as it is accompanied by the emergence of new, specific needs related to age. Condition changes also appear, which are predictable and refer mainly to physical complaints. Lee and Tideswell (2005), as well as Garcia and Martorell (2007) point at the age of 60 years as an important time point of changes; in the majority of people, this is when the life rhythm is modified and needs different from those present so far arise. Walker (2004) distinguishes as many as four categories of senior age: the group of people at the pre-retirement age and those who have retired earlier (55-64 years of age); the group of the retired (65-74 years of age); the group of elder pensioners (75-84 years of age); the group of people at the age of 85 or more. Dąbrowski (2006), in turn, divides seniors into three basic groups: people advanced in years (60-75 years of age); people of old age (76-90 years of age); long-lived people, i.e. those older than 90 years of age. The World Health Organisation suggests a similar classification, and the United Nations point at the age of 65 as the old age threshold (Kowalik, 2009).

\section{Senior tourism}

Senior tourism, i.e. tourism of elderly people is included, among others, within social tourism regarding people whose life situation makes it entirely or partly impossible for them to partake in tourism. This can result from economic factors, physical impairment, isolation, restricted mobility. Among these groups, as Górska points out (2010), apart from children, youth, and families, elderly people are of special interest.

Senior tourism is often mentioned in the context of tourism of the disabled. Buhalis and Darcy (2011), when discussing groups of the disabled, enumerate elderly people among them - beside those with impaired mobility or those with temporary impairment, e.g. children under 6 years of age. Age, constituting one of the impairment criteria because of the specificity of the human body functioning, is also indicated in the Spanish language literature referring to tourism. Gonzalez (2008) points at elderly people as one of the three groups remaining within the range of research on tourism of the disabled. The potential of the group with regard to tourism available in the context 
of demographic changes is described by Darcy and Dickson (2009), as well as by Widawski (2010, 2011).

Tourists' motivations are diverse, and this applies also to seniors. It would be difficult to point at a single, leading reason for tourist migrations in this group. They depend, as in the case of other groups, on the economic status, education, physical condition, or habits. Among the most significant reasons, the need to rest and relax are enumerated in the subject literature (Horneman et al., 2002; Lee, Tideswell, 2005). The need to meet other people and to make new acquaintances are emphasised by Acevedo (2003) or Huang and Tsai (2003). The reasons for tourist trips in the group of seniors also include the simple need to discover new destinations, with their cultural and natural attractions that the seniors have always planned to visit (Horneman et al., 2002); visiting relatives plays an important part, too. Moreover, the number of health-related stays in resorts and spa \& wellness centres is rising (Widawski, 2011).

The seniors' behaviour on the tourist market can also be specific (Alén, Domínguez, Losada, 2012). The choice of accommodation depends on the trip character and the participants' income; however, there is a demand for maintaining a minimum standard, which determines the fact if the senior benefits from the offer. The length of the senior's trip is obviously variable; the farther the journey, the longer its time, a dependence observable also in other groups. One can still note that seniors dedicate more time for tourism than the rest of the population. What is also significant is the source of information that seniors use when taking the decision regarding a tourist trip. Most often they rely on their own long-term experience as consumers of the tourist offer. They usually gather information personally from their relatives, friends, neighbours. The mouth-to-mouth model of passing information dominates. An essential source of information is also press, willingly read by the majority of elderly people (Horneman et al., 2002).

It is worth to attempt to verify, at least partially, the functioning of senior tourism in Lower Silesia on the basis of seniors' own opinions. This is why a study was performed among members of the 'FAN' Association for Sport Promotion in Wrocław who are engaged in tourism.

\section{'FAn' Association for Spopt Promotion}

The Association was established in 2005 by members of the Gwardia Wrocław Sports Fan Club. At present, it unites 193 people bound with sport and recreation who want to develop their skills and share knowledge and experience. Within the Association, two sections were created which are oriented at elderly people, namely: the Active Senior Club and 50+ Footballers.

The former came into being in 2010. Now it has 86 members. The main statute aims are activating seniors, and developing and propagating elderly people's creative activity. The goals are accomplished through organising regular meetings or events of recreational and tourist character, such as: Club meetings (meetings or lectures with sportspersons or travellers, lectures on physical condition and good health), recreational events (various motor activities, such as integration games, gymnastics, dancing classes or pools, including sauna and wellness spheres), Nordic walking for $60+$ seniors (since 2008). The 50+ Footballers section was established in 2014 in the initiative of 
former footballers from the clubs of Wrocław. The founding meeting took place on March 20, 2014. Among other activities, there are trips: multigenerational bicycle trips (the city of Wrocław and the vicinity, planned foreign trips to Spreewald, or a trip along the Danube from Vienna through Bratislava to Budapest), and sightseeing trips to get to know the cultural and natural attractions of the region and of the neighbouring countries (the schedule for 2015 includes 11 routes).

\section{Methodology}

\section{Research on the tourist activity of seniors from the 'FAnl' Association for Sport Promotion and their socio-economical chapacteristic}

The main aim of the research was to describe the phenomenon of senior tourism in the tourist space of Lower Silesia, on the example of a group belonging to the 'FAN' Association for Sport Promotion. The basic questions put forward in the study referred to such fundamental areas as the main motives for tourist migrations in the group being discussed, the forms of tourism preferred by seniors, and the impact of tourism on their lives.

The inquiry research was performed in the period between April and May 2015. It was anonymous in character, and the respondents were members of the 'FAN' Association for Sport Promotion. The questionnaire consisted of 16 questions. It was presented to the respondents in three ways: one part of them received the questionnaire electronically, one part were examined during the Active Senior Club meetings, and the rest were handed the questions during the work-outs of the 50+ Footballers section. In total, 68 members of the Association took part in the research. The limited generalizability of the research sample should be here stressed. It can be treated as representative for the members of senior sport associations of Wrocław. These are however survey studies being just an introduction to further complex research on specificity of Lower Silesia seniors' tourist activity.

The research group consisted of women in $63 \%, 37 \%$ were men. The participants were seniors over 55 years of age. When taking into account a detailed division by age, the most numerous group (31\%) were the Association members aged 65-69 years. The following groups were, almost equal in number (29\% and $28 \%$, respectively), the group of younger seniors, aged 55-59 years, and the group of those aged 60-64 years. The least numerous, for obvious reasons, was the group of elderly seniors, aged 70 years or older (it constituted only $12 \%$ of the studied seniors).

The distribution by professional activity was almost equal in the group. There are slightly more (51\%) people who are not professionally active any more; the rest declare some form of professional activity.

As far as the education of the researched Association members is concerned, the definitely most frequent declaration is higher education, represented by almost half of the studied seniors (49\%). The following locations were secondary education (41\%), vocational education (7\%), and primary education $(3 \%)$.

Practising tourism is bound with a specific economic status: a potential tourism participant should have certain financial resources, although it is worth to emphasise that recreation and tourism 
can also be practised without bearing significant costs, if any. Therefore, rather than asking about the person's income, it would be more appropriate to find out how they perceive their economic situation; it is in fact this subjective factor that seems significant for taking financial decisions with regard to various activities, including tourist or recreational activities. This is why the respondents were asked to assess their economic status. Half of them perceive the situation as good, and another $16 \%$ as very good. One third of the participants (32\%) considered their economic status to be average, and $2 \%$ evaluated their household financial status as bad. None of the respondents pointed at the 'very bad' choice. These results are symptomatic, especially in the context of the relatively bad economic status of pensioners in Poland, if measured with the average retirement benefit.

\section{Resullts and discussion}

A significant factor bound with senior tourism is the seniors' assessment of their health status. A vast majority of the respondents consider their health condition to be good or very good. One fourth do not declare any health problems and feel very good, and 53\% perceive their health status as good. Among the remaining $22 \%$ there are those who assess their condition as average (18\%), those who claim that their situation is definitely bad ( $1 \%$ only), and those who have problems with defining their real health status and therefore chose the answer 'hard to say' (3\%). Thus the results unquestionably reveal the seniors' appropriate condition and approach to practise tourism and recreation. This is of significant importance, as bad health condition in enumerated among the main inhibitors of senior tourism development.

After the general disposition to practising tourism and recreation had been studied, the respondents were asked to point at the preferred forms of passive and active resting. Among the passive forms, reading books turned out the most popular - it was chosen by 44 people. Another activity, similar in character, was reading newspapers, pointed by 33 people. The remaining two activities were watching television and surfing the Internet: each indicated by 22 people. Only 1 person preferred the intellectual entertainment of playing chess.

Considering the character of tourism, the question about active resting seems much more significant (Figure 1).

The majority of choices referred to sightseeing trips (40 people). Cycling turned out almost equally popular. The following two forms were bound with hiking recreation: 33 people pointed at walking, 28 at Nordic walking. The groups choosing swimming and skiing were comparable in number ( 25 and 24 people, respectively), the latter not specifying whether they practised crosscountry or downhill skiing. Mountain trips, specific because of the landform and the landscape, were pointed at by 19 people; football was chosen by 8 , although one can assume this answer to be bound with the circumstances of the data collection, which took place during a football work-out of the $50+$ seniors.

The question concerning the subjective assessment of the respondents' own level of physical activity can be treated as a conclusion to this part of the research. In this case, slightly more than half of the participants (53\%) declare that their level of physical activity has decreased as compared 
with the previous years; at the same time, they utter a need to come back to the former situation. The rest state that their present level of physical activity has not changed as compared with the previous years.

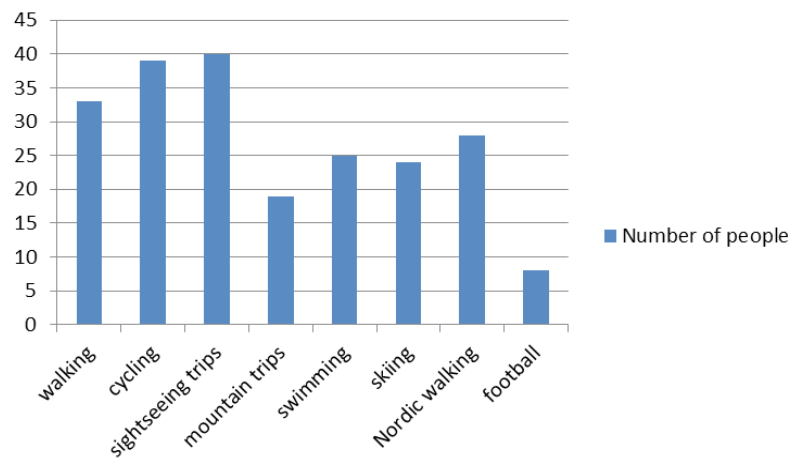

Figure 1. Forms of active resting preferred by the respondents

Source: own elaboration.

Having these data in mind, let us analyse the specificity of the tourist activity declared by the researched senior group A vast majority of the respondents travel more often than once a year. The most numerous group (53\%) travel with tourist aims several times (2-3 times) a year, and ca. one third (35\%) take tourist trips even more often than several times a year. This means that in the case of $88 \%$ of the studied seniors tourist trips occupy a significant part of the free time; $9 \%$ of the respondents travel not more than once a year, and 3\% travel less frequently than once a year.

Taking into consideration the preferences observed in the participants, five groups of tourist trip aims were suggested: resting trips, health resort trips, sightseeing trips, visiting friends or relatives, and active tourism (Figure 2).

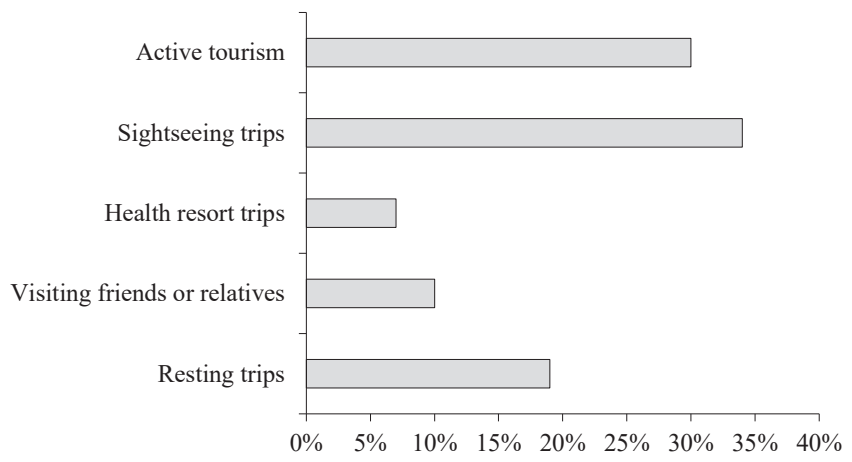

Figure 2. Aims of tourist trips in the group of respondents

Source: own elaboration. 
Sightseeing trips are definitely the most popular in the researched group; they were pointed at by more than one third of the respondents. Travels bound with practising active tourism are only slightly less popular. These two aims dominate. Resting trips occupy the third position (19\%). Visiting friends or relatives was declared as the tourist aim by $10 \%$ of the participants, although in world tourism these two aims are considered to be the most frequent (UNWTO Tourism Highlights, 2015). Health resort trips turned out to be the least significant (7\%), which can be a little surprising if one considers the character of the studied group; on the other hand, if $78 \%$ of the respondents declare good or very good health condition, the limited preference of the healthrelated tourist aim should not be astonishing. The results correspond in some way with the research conducted by Śniadek (2007). Similarly one of the most popular destination of national trips were visits at relatives' and friends', sightseeing and resting visits, and (in smaller degree however) the health resort trips.

When asked about the reasons for travelling, the respondents most often pointed at their need to experience something new, one of the motivations described in the literature on the subject (Figure 3).

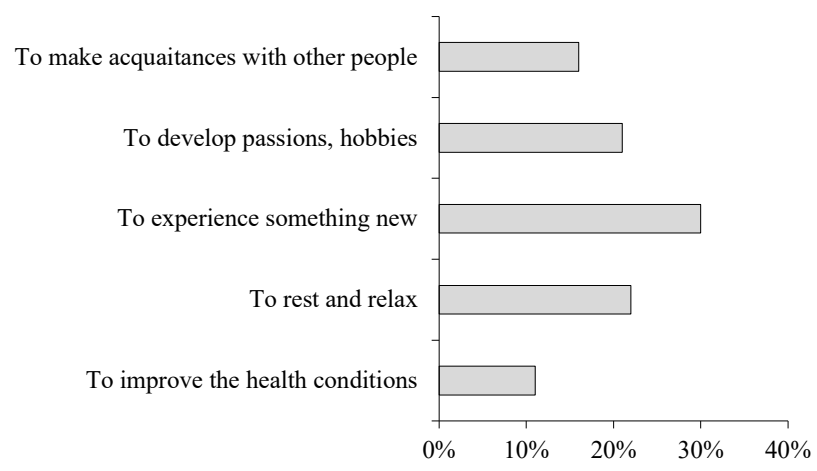

Figure 3. Motives for tourist trips in the researched group

Source: own elaboration.

This option was chosen by $30 \%$ of the respondents; the fact corresponds with a wider trend of the need to make up for the time lost in the earlier phases of life, i.e. the period of everyday routine of functioning between the household and the workplace. Among the respondents, $21 \%$ want to develop their passions, hobbies, and interests during a tourist trip. For many seniors, also those participating in the present research, this is an ideal moment to gather new experience.

Rest and relaxation are an obvious motive for tourist trips, not only in the age group being discussed. It was pointed at by $22 \%$ of the respondents, which places the motive at the second location. The following motives chosen in the analysed questionnaires were: the need to make acquaintances with other people (16\%) - a motive significant in the group in which a considerable rise in the number of single households is observed - and the need to improve one's health condition, most 
significant for $11 \%$ of the respondents, also comprehensible if one takes into account the specificity of seniors' physical condition.

In turn, considering the inhibitors of tourism development in the senior age group, it is worth to emphasise that slightly more than one third of the research participants $(36 \%$, the most numerous choice) declare no obstacles that would make it difficult or impossible for them to practise tourism (Figure 4).

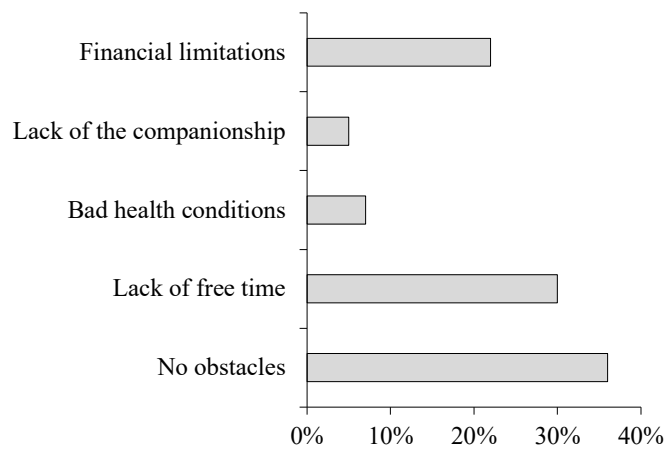

Figule 4. Inhibitors of practising tourism among the respondents

Source: own elaboration.

The second position in the rating is seemingly surprising; it refers to the first significant obstacle, i.e. lack of free time. It bothers $30 \%$ of the respondents. On the one hand, this results from a relatively high level of professional activity in the researched group, which was discussed earlier; on the other hand, it is certainly bound with family situation. The model of family functioning in the Polish society comprises, among others, the multigenerational paradigm, in which not only parents, but also grandparents take part in upbringing children; the role of seniors is especially important if their children present a high level of professional activity.

The next most frequent choice (the obstacle pointed at by $22 \%$ of the respondents) refers to financial limitations, connected with the general situation of pensioners in the Polish reality. Other obstacles are perceived as sources of difficulties in taking tourist trips to a much smaller degree. For $7 \%$ of the participants the problem consists in bad health condition, 5\% declare lack of companionship as the main inhibitor.

These results do not correspond entirely with the obstacles most often pointed at by the Polish seniors. The literature indicates two main factors limiting seniors tourist activity: financial (Szpara 2015, Śniadek 2007) or health conditions (Grzelak-Kostulska, Hołowiecka, 2012; MokrasGrabowska, 2010; Myck et al., 2009). Probably it stems from the sampling method - research was conducted on the a group of seniors of relatively high level of physical activity.

The last group of questions referred to the tourist offers that seniors took advantage of. The question if the offer addressed to the respondents was attractive was answered positively by 36 
people (53\%). Only 9 people (13\%) denied, and the remaining $23(34 \%)$ had no specific opinion on the subject. Asked about the source of information on the tourist offers, the seniors most often pointed at friends and relatives, who are the basic source for 39\% of the respondents (Figure 5). The results correspond with other research present in Polish literature (e.g. Szpara, 2015; Skorupa, Bogacz, 2015), where the meaning of whisper marketing is stressed in promotion of tourist offer in a group of seniors.

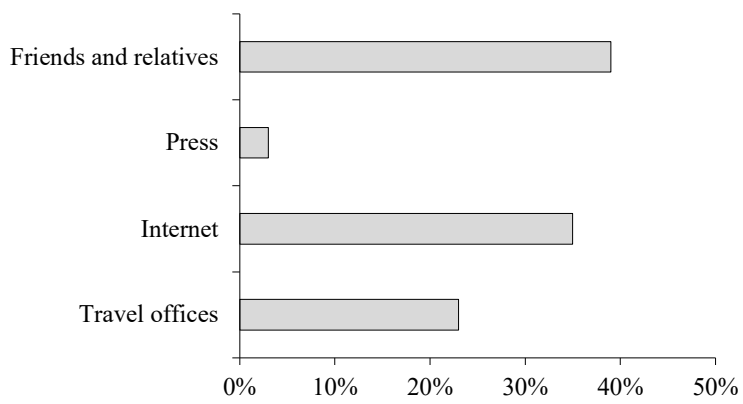

Figure 5 . Sources of information on the tourist offer as declared by the respondents Source: own elaboration.

Slightly fewer, i.e. $35 \%$ of respondents stated that Internet was their fundamental source of information, which could be surprising if one considers the distrust still aroused by the medium among elderly people. Almost every fourth respondent (23\%) takes advantage of travel office services, and the smallest group of seniors rely on press in this matter.

The survey also included one open question concerning tourist offer assessment; the respondents were encouraged to determine significant elements, in their opinion, that are lacking in the tourist offer addressed to seniors. The answers enumerated lack of offers for active free time management for single seniors, as well as not considering the specific needs of the group, such as organising nearby, not tiresome, inexpensive trips connected with sightseeing; concerts; or shortterm and inexpensive trips.

\section{Conclusion}

Attempting to grasp the research results synthetically, one should point at some dependencies. Among the respondents, the dominating level of education is higher education, which definitely influences a rise in tourist activity, practised repeatedly in a year by the vast majority of the surveyed seniors. This is not surprising, especially if the obstacles are neither financial problems (these concern as few as every fifth research participant) nor physical condition (as many as 78\% of respondents are satisfied with it, with only $1 \%$ assessing their health condition as bad). Practising tourism is certainly related with taking care of an appropriate level of physical activity, which has 
remained unchanged for years in almost half of the surveyed seniors. The most frequently chosen tourist forms are sightseeing trips and broadly understood active tourism.

Seniors partaking in tourist trips miss original, stereotype-breaking offers, especially as the most frequent motives for tourist trips declared by the researched members of the Association are the needs to experience something new, to develop passions, to relax and rest; improvement of health condition appears further in the hierarchy.

According to seniors, the perspectives for senior tourism development depend also on an increase in the tourist offer quality. Asked about considerable imperfections in this area, the respondents pointed at the lack of offers for seniors travelling alone or lack of financial support.

Although many details demand precise specification and improvement, the fundamental conclusion brought about by the research allows to clearly determine the perspectives for senior tourism development in Lower Silesia: the offer is already operating, the potential group of its recipients are willing to benefit from it, and, if the market adjusts to the consumers' expectations, the perspectives for senior tourism development seem promising.

\section{Reéerences}

Acevedo, C.R. (2003). Motivos para viajar: um estudio com turistas maduros no contexto brasileiro. FACEP Pesquisa, $6(3), 78-87$.

Alcaide Casado, J.C. (2005). Dónde está el marketing para mayores? Marketing + Ventas, 205, 46-57.

Alén, E., Domínguez, T., Losada, N. (2012). New Opportunities for the Tourism Market: Senior Tourism and Accessible Tourism. In: M. Kasimoglu (ed.), Visions for Global Tourism Industry. Creating and Sustaining Competitive Strategies (pp. 139-166). Rijeka: InTech.

Buhalis, D., Darcy, S. (2011). Introduction: From disabled tourists to accessible tourism. In: D. Buhalis, S. Darcy (eds.), Accessible Tourism: Concepts and Issues (pp. 1-20). Bristol: Chanel View Publications.

Dąbrowski, A. (ed.) (2006). Zarys teorii rekreacji ruchowej. Warszawa: ALMAMER Wyższa Szkoła Ekonomiczna, Akademia Wychowania Fizycznego.

Darcy, S. (2006). Setting a research agenda for accessible tourism. Gold Coast: CRC for Sustainable Tourism Pty Ltd.

Darcy, S., Dickson, T. (2009). A Whole of Life Approach to Tourism: the Case for Accessible Tourism Experiences. Journal of Hospitality and Tourism Management, 16 (1), 32-43.

Garcia Sastre, M.A., Martorell Cunill, O. (2007). Una reflexión sobre el modelo turistico de las Illes Balears. In: Decisiones basadas en el conocimiento y en el papel social de la empresa (vol. 1, pp. 1097-1106). Palma de Mallorca: AEDEM.

Gonzalez Velasco, D. (ed.) (2008). El mercado potencial del turismo accesible para el sector turístico español, Julio 2008, Ministerio de Industria, Turismo y Comercio, Madrid.

Górska, E. (2010). Turystyka społeczna jako forma aktywizacji rynków turystycznych na przykładzie programów turystyki społecznej w Hiszpanii. Acta Scientiarum Polonorum, Oeconomia, 9 (4), 133-142.

Grzelak-Kostulska, E., Hołowiecka, B. (2012). Turystyka osób starszych w Polsce - uwarunkowania społecznodemograficzne. Problemy polityki turystycznej, Prace Naukowe Uniwersytetu Ekonomicznego we Wrocławiu, 259, 95-108.

Horneman, L. et al. (2002). Profiling the Senior Traveler: An Australian Perspective. Journal of Travel Research, 41 (1), $23-37$.

Hossain, A., Bailey, G., Lubulwa, M. (2003). Characteristics and Travel Patterns of Older Australians: Impact of opulation Ageing on Tourism. International Conference on Population Ageing and Health Modelling our Future, Canberra.

Huang, L., Tsai, H.T. (2003). The study of senior travelers in Taiwan. Tourism Management, 24, 561-574.

Kowalik, S. (ed.) (2009). Kultura fizyczna osób z niepetnosprawnością. Gdańsk: Gdańskie Wydawnictwo Psychologiczne. 
Lee, S.H., Tideswell, C. (2005). Understanding attitudes towards leisure travel and the constraints faced by senior Koreans. Journal of Vacations Marketing, 11 (3), 249-263.

Mokras-Grabowska, J. (2010). Program „Europe Senior Tourism” - założenia, realizacja, efekty ekonomiczne (pp. 7188). In: A. Stasiak (ed.), Turystyka społeczna w regionie tódzkim, Łódź: Wydawnictwo WSTH.

Myck, M., Czapiński, J., Dorabialski, W., Gilis-Januszewska, A., Kalbarczyk, M., Kula, G., Nicińska, A., Topór-Mądry, R., Wiśniewski, M. (2009). Zdrowie, praca i styl życia populacji 50+w Polsce na tle innych krajów Europy. CenEA Research Note series RNO2pl/09, Available at: www.cenea.org.pl.

Rudnicki, L. (2010). Zachowania konsumentów na rynku turystycznym. Kraków: Proksenia.

Skorupa, A., Bogacz, A. (2015). Aktywność turystyczna w późnej dorosłości i starości. Motywacja, postawy i dobrostan psychiczny. Społeczeństwo i Edukacja, 17 (2), 207-220.

Śniadek, J. (2006). Age of seniors - a challenge for tourism and leisure industry. Studies in Physical Culture and Tourism, 13, Suppl., 103-105.

Śniadek, J. (2007). Konsumpcja turystyczna polskich seniorów na tle globalnych tendencji w turystyce. Gentrologia Polska, 15 (1-2), 21-30.

Szpara, K. (2015). Aktywność turystyczna seniorów - na przykładzie turystów-obcokrajowców przebywających na terenie województwa podkarpackiego w 2012 roku. Ekonomiczne Problemy Turystyki, 1 (29), 287-302.

UNWTO Tourism Highlights (2015). Madrid: World Tourism Organization.

Walker, M.C. (2004). Marketing to seniors, 1st Books Library, Bloomington.

Widawski, K. (2010). Accessibility and the character of the information about tourist values in the Internet on the example of the folklore events. In: J. Chromý (ed.), Trendy komunikace v cestovním ruchu (pp. 94-113). Praha: Verbum.

Widawski, K. (2011). Accessible tourism starts with the accessible information. Madrid case study (pp. 298-310). In: J. Wyrzykowski, J. Marak (eds.), Tourism Role in the Regional Economy. Social, Health-Related, Economic and Spatial Conditions of Disabled People's Tourism Development. Wrocław: University of Business in Wrocław.

\section{AKTYWNOŚĆ TURYSTYCZNA WŚRÓD SENIORÓW: CHARAKTERYSTYKA NA WYBRANYCH PRZYKŁADACH}

SŁOWA KLUCZOWE STRESZCZENIE turystyka senioralna, motywacje turystyczne, czynniki hamujące rozwój turystyki, oferta turystyczna

Artykuł dotyczy funkcjonowania i perspektyw rozwoju turystyki senioralnej. Analizę przeprowadzono na podstawie opinii członków dwóch aktywnych sekcji stowarzyszenia zajmującego się promocją zdrowia. Analizę ankiet poprzedza krótka prezentacja działalności stowarzyszenia. Badanie przeprowadzono na 68 seniorach. Pytania ankietowe dotyczyły czterech głównych tematów: dane osobowe oraz dotyczące stanu zdrowia, preferowane formy aktywności rekreacyjnej, główne cele podróżowania i motywacji turystycznej oraz najważniejsze czynniki hamujące aktywność turystyczną respondentów. Grupę badanych poproszono także o ocenę oferty turystycznej widocznej na rynku Dolnego Śląska ze szczególnym uwzględnieniem czynników, które warto byłoby w niej zmienić. 